FEB 51968

\title{
CEND-3742-329 MASTER
}

\author{
VANADIUM \\ PURIFICATION
}

FIFTH QUARTERLY PROGRESS REPORT

POWER

DEP.ARTMENT

Issued January, 1968

DISTRIBUTION OF THIS DOCUMENT IS UNLIMITED. 


\section{DISCLAIMER}

This report was prepared as an account of work sponsored by an agency of the United States Government. Neither the United States Government nor any agency Thereof, nor any of their employees, makes any warranty, express or implied, or assumes any legal liability or responsibility for the accuracy, completeness, or usefulness of any information, apparatus, product, or process disclosed, or represents that its use would not infringe privately owned rights. Reference herein to any specific commercial product, process, or service by trade name, trademark, manufacturer, or otherwise does not necessarily constitute or imply its endorsement, recommendation, or favoring by the United States Government or any agency thereof. The views and opinions of authors expressed herein do not necessarily state or reflect those of the United States Government or any agency thereof. 


\section{DISCLAIMER}

Portions of this document may be illegible in electronic image products. Images are produced from the best available original document. 
(1)

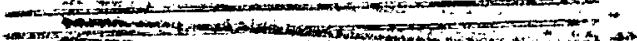

$\rightarrow$ stren

PENOAGEAAIEN-GLEARANCE

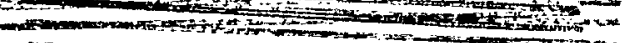
rom 
CEND-3742-329

UC-25, Metals, Ceramics and Materials

TID-4500; 5 lst Edition

\section{VANADIUM PURIFICATION}

FIFTH QUARTERLY

PROGRESS REPORT

For Period

October 1 to December 31, 1967

Prepared by:

C. T. Wang, Wah Chang, Albany, Oregon E. F. Barock, Wah Chang, Albany, Oregon

J. C. La Vake, CENPD

S. S. Christopher, CENPD

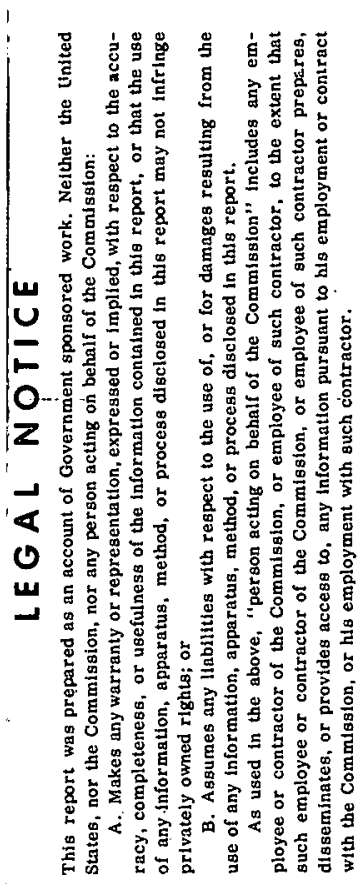

Contract AT(30-1) -3742

U.S. Atomic Energy Commission

Issued January 1968
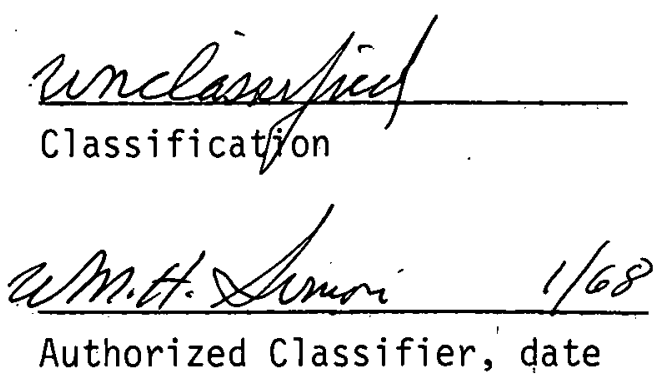

Approved by

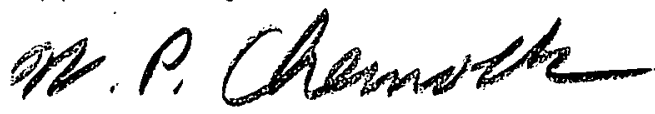

W. P. Chernock, Manager

Nuclear Laboratories 
CEND-3742-329

UC-25, Metals, Ceramics

and Materials

TID-4500, 5lst Edition

EXTERIAL DISTRIBUTION

No. of Copies

Mr. W. O. Harms

1

Oak Ridge National Laboratory

Post Office Box X

Oak Ridge, Tennessee

Mr. T. T. Claudson

Pacific Northwest Laboratory

Battelle Memorial Institute

Post Office Box 999

Richland, Washington 99352

Mr. S. J. Paprocki

Battelle Memorial Institute

Columbus, Ohio

Mr. O. N. Carlson

Iowa State Institute of Atomic Research Ames, Iowa

Mr. D. J. McPherson

1

IIT Research Institute

10 West 35th Street

Chicago, Illinois 60616

Mr. C. E. Weber

Atomics International, Inc.

Canoga Park, California

Mr. L. R. Weissert

Babcock \& Wilcox Company

Atomics Energy Division

Lynchburg, Virginia

Mr. E. L. Zebroski

General Electric Laboratory

Vallecitos Atomic Laboratory

Post Office Box 1131

San Jose, California

Mr. J. A. McGurty

General Electric Company

Cincinnati, Ohio

Mr. R. C. Werner

Mine Safety and Appliance Company

230 North Braddock Avenue

Pittsburgh, Pennsylvania 15208 
CEND-3742-329

UC-25, Metals, Ceramics

and Materials

TID-4500, 5lst Edition

EXTERNAL DISTRIBUTION

No. of Copies

Mr. J. Edward Fox

2

Fuels and Materials Branch

U. S. Atomic Energy Commission

Division of Reactor Development and Technology.

Washington, D. C. 20545

Mr. Jules M. Simmons, Chief

Fuels and Materials Branch

U. S. Atomic Energy Commission

Division of Reactor Development and Technology Washington, D. C. 20545

Mr. K. A. Trickett

Fuels and Materials Branch

U. S. Atomic Energy Commission

Division of Reactor Development and Technology

Washington, D. C. 20545

Dr. Glenn W. Wensch, Chief

Liquid Metal Projects Branch

U. S. Atomic Energy Commission

Division of Reactor Development and Technology

Washington, D. C. 20545

U. S. Atomic Energy Commission

New York Operations Office

376 Hudson Street

New York, New York 10014

Attention: Development Contract Division

U. S. Atomic Energy Commission

1

New York Operations Office.

376 Huds on Street

New York, New York 10014

Attention: NYO Library

Mr. H. S. Potter, Chief

1

New York Operations Office

U. S. Atomic Energy Commission

Brookhaven Office

Upton, New York 11973

U. S. Atomic Energy Commission

Division of Technical Information Extension

Post Office Box 62

Oak Ridge, Tennessee 
CEND-3742-329

UC-25, Metals, Ceramics and Materials TID-4500, 5lst Edition

EXTERNAL DISTRIBUTION

No. of Copies

Mr. G. Merckel

1

U. S. Atomic Energy Commission

Hartford Branch

Post Office Box 500

Windsor; Connecticut 06095

Mr. Leo Graup, Authorized Representative

1

U. S. Atomic Energy Commission

New York Operations Office

376 Hudson Street

New York, New York 10014

Mr. L. Kelman

Argonne National Laboratory

9700 South Cass Avenue

Argonne, Illinois

Mr. J. H. Kittel

Argonne National Laboratory

9700 South Cass Avenue

Argonne, Illinois

Dr. D. H. Gurinsky

Brookhaven National Laboratory

Upton, L. I. New Yori 11973

Mr. R. D. Baker

Los Alomos Scientific Laboratory

Los Alamos, New Mexico 87544

Mr. P. Patriarca

Oak Ridge National Laboratory

Post Office Box X

Oak Ridge, Tennessee

Mr. R. E. Macherey

Argonne National Laboratory

9700 South Cass Avenue

Argonne, Illinois 
CEND-3742-329

UC-25, Metals, Ceramics

and Materials

TID-4500, 5lst Edition

EXTERNAL · DISTRIBUTION

Mr. R. J. Van Thyne

IIT Research Institute

10 West 35 th Street

Chicago, Illinois 60616

Mr. K, Puechl

Nuclear Materials and Equipment Corporation Apollo, Pennsylvania

Mr. A. Strasser.

United Nuclear Corporation

Fuels Division

New Haven, Connecticut

Dr. R. J. Allio

Westinghouse Electric Corporation

Atomic Power Department

Post Office Box 1075

Pittsburgh, Pennsylvania
1

No. of Copies

1

1

1 
CEND-3742-329

UC-25, Metals, Ceramics and Materials

TID-4500, 5lst Edition

\section{VANADIUM PURIFICATION}

TABLE OF .CONTENTS

Page No.

I. ABSTRACT

1

II. INTRODUCTION

2

III. EXPERIMENTAL EFFORT

4

IV. DISCUSSION OF RESULTS

11

V. FUTURE WORK

14 
CEND-3742-329

UC-25, Metals, Ceramics

and Materials

TID-4500, 5lst Edition

\section{VANADIUM PURIFICATION}

LIST OF TABLES

\section{Page No.}

I. Chemical Analysis Ingot \#3 Derby Analysis (ppm)

II. Chemical Analysis Ingot \#3.

Consolidation Ingot Analysis (ppm)

III. Chemical Analysis Ingot \#3

2nd Electron Beam Ingot Analysis (ppm)

IV. Chemical Analysis Ingot \#3

Arc Doped Ingot Analysis (ppm)

V. $\because$ Chemical Analysis Ingot \#3

Final Electron Beam Ingot Analysis (ppm)

VI. Chemical Analysis Ingot \#4.

Derby Analysis (ppm)

VII. Chemical Analysis Ingot \#4

Consolidation Ingot Analysi's (ppm)

VIII. Chemical Analysis Ingot \#4

Final Electron Beam Ingot Analysis (ppm) 
CEND-3742-329

UC-25, Metals, Ceramics

and Materials

TID-4500, 5lst Edition

\section{VANADIUM PURIFICATION}

LIST OF FIGURES

Following Page No.

1. Effect of Vacuum Melting on the Hardness Reading of Vanadium

2. Effect of Vacuum Melting on the Oxygen Content in Vanadium

3. Effect of Vacuum Melting on the Carbon Content in Vanadium

4. Effect of Vacuum Melting on the Nitrogen Content in Vanadium

5. Effect of Vacuum Melting on the Silicon Content in Vanadium 
ABSTRACT

During this report period, 117 pounds of high purity vanadium were produced by a commercial process to meet the contract requirements. Additional material is being produced to demonstrate the repeatability of the process and to provide additional back-up material.

The process developed for the production of the high purity vanadium is as follows:

1. Aluminothermic reduction of $\mathrm{V}_{2} \mathrm{O}_{5}$

2. Consolidation by electron beam melting the reduced vanadium

3. Second electron beam melting

4. Yttrium vacuum-arc doping

5. Final electron beam melting. 
This program was initiated to produce a 100 pound, high purity vanadium ingot by a process suitable for commercial applications. This material will be used as feedstock for producing a high purity, V-15 Cr-5 Ti, alloy ingot. Mechanical pro-perties of the alloy will be determined to evaluate the effect of purity on the tensile, stress rupture and weld characteristics of the alloy.

Prior to work performed during this quarter, two vanadium ingots were produced which did not fully meet the following target requirements of this program:

1. Weight

Approximately 100 pounds

2. Chemistry

$\begin{array}{ll}\left.\begin{array}{l}\text { oxygen } \\ \text { nitrogen } \\ \text { carbon } \\ \text { hydrogen }\end{array}\right\} \leq 500 \mathrm{ppm} \\ \text { silicon } & \leq 500 \mathrm{ppm} \\ \text { aluminum } & \leq 1000 \mathrm{ppm} \\ \text { iron } & \leq 1000 \mathrm{ppm}\end{array}$

\section{Process}

By a reproducible, commercial process.

The first ingot produced was high in silicon and was contaminated by the reactant aluminum used for the aluminothermic reduction of $\mathrm{V}_{2} \mathrm{O}_{5}$. 
The second ingot had a high initial oxygen content due to insufficient excess aluminum in the reduction process. Two extra electron beam melts were required and resulted in an ingot of insufficient weight.

Fabrication of the third ingot followed the outlined process and meets the requirements of the contract. Details of the processing of this third ingot are included in this report.

The fourth ingot is serving to demonstrate process reproducibility and to provide additional back-up material. 


\section{EXPERTMENTAL EFFORT}

During this quarter, 117 pounds of high purity vanadium (Ingot No. 3) were produced by the commercial process outlined in the Abstract of this report.

Aluminothermic reductions for the third ingot were processed and double electron beam melted during the last quarter. As reported in CEND-3742-325, seven derbies, totaling 342 pounds, were reduced with excess aluminum to allow residual aluminum in the reductions to aid in removing oxygen during electron beam melting. Table I gives the chemical analyses of the seven derbies.

During the consolidation of the derbies, the unmelted portion of the feedstock separated from the feedstock holding stub, causing a premature furnace shutdown. The melted portion, 139 pounds, was designated Heat Number 940014-V-XIA. The separated section was then melted into a 94 pound ingot, Heat Number 940017-V-XIA. The chemical and hardness data for both ingots are given in Table II.

The two consolidated ingots were welded together and used as the feedstock for the second electron beam melted ingot, 204 pounds, Heat Number 940020-V-53B. The chemical analyses and hardness data are shown in Table III. The section of the ingot which had a much higher hardness than the remainder was removed. This practice is typical of that used in commercial melting of columbium and zirconium ingots.

During this quarter, the balance of the ingot was vacuum-arc doped with yttrium, and final electron beam melted.

The doped ingot, designated Heat Number 6-950048-Y-Y weighed 147 pounds. The chemical and hardness data are shown in Table IV. The oxygen values noted, are not representative of the ingot because the oxygen content is not homogeneous, and is combined with the yttrium. 
TABLE I

CHEMICAL ANALYSIS INGOT \#3

Derby Analysis (ppm)

\begin{tabular}{l|c|c|c|c|c}
\hline Derby No. & C & O & H & N & Si \\
\hline $8-7-67$ & 80 & 1,300 & 50 & 70 & 600 \\
$8-8-67$ & 50 & 1,400 & & 45 & 400 \\
$8-9-67$ & 140 & 3,900 & & 115 & 400 \\
$8-10-67$ & 90 & 10,100 & 47 & 144 & 300 \\
$8-11-67$ & 120 & 14,400 & & 230 & 300 \\
$8-24-67$ & 150 & 1,400 & 34 & 200 & 270 \\
$8-25-67$ & 100 & 4,360 & 31 & 400 & 260 \\
\hline
\end{tabular}

TABLE II

CHEMICAL ANALYSIS INGOT \#3

Consolidation Ingot Analysis (ppm)

\begin{tabular}{|c|c|c|c|c|c|c|}
\hline Heat No. & $\mathrm{C}$ & 0 & $\mathrm{H}$ & $\mathbb{N}$ & $\mathrm{Si}$ & $\begin{array}{l}\text { Hardness, BHN } \\
300 \mathrm{~kg} \text { Load }\end{array}$ \\
\hline \multicolumn{7}{|l|}{$940014-V-X] \cdot A$} \\
\hline Top & 550 & 1,600 & 11 & 225 & 690 & 375 \\
\hline Center & 500 & -- & -- & 95 & 610 & 156 \\
\hline Bottom & 500 & 320 & 8 & 125 & 350 & 96 \\
\hline $9400017-V-X 1 A$ & & & & & & \\
\hline Top & 460 & 6,500 & 26 & 260 & 440 & 163 \\
\hline Center & 470 & 1,000 & 3 & 125 & 440 & 192 \\
\hline Bottom & -- & -- & -- & -- & -- & 107 \\
\hline Average & 496 & 2,355 & 11 & 166 & 506 & 181 \\
\hline
\end{tabular}


TABLE III

CHEMICAL ANALYSIS INGOT \#3

2nd Electron Beam Ingot Analysis (ppm)

\begin{tabular}{c|c|c|c|c|c|c}
\hline Heat No. & C & O* & H & N & Si & $\begin{array}{c}\text { Hardness, BHN } \\
\text { 300 kg Load }\end{array}$ \\
\hline 940020-V-53B & & & & & & \\
Top I & 60 & 640 & 9 & 135 & 420 & 96 \\
3 & 60 & & & 305 & 350 & 254 \\
4 & 50 & 360 & 9 & 350 & 460 & 96 \\
Bottom 5 & 100 & 440 & 6 & 250 & 870 & 165 \\
\hline Average & 64 & 480 & 8 & 232 & 542 & 158 \\
\hline
\end{tabular}

TABLE IV

ARC DOPED INGOT ANALYSIS (ppm)

\begin{tabular}{c|c|c|c|c|c|c}
\hline Heat No. & C & O* & H & N & Si & \multicolumn{2}{|c|}{$\begin{array}{c}\text { Hardness, BHN } \\
300 \mathrm{~kg} \text { Load }\end{array}$} \\
\hline 6-950048-VY & & & & & & \\
\hline Top 1 & 60 & 610 & -- & 175 & 440 & 69 \\
2 & 50 & & -- & 185 & 570 & 74 \\
3 & 60 & 1,060 & -- & 185 & 700 & 77 \\
4 & 50 & & -- & 160 & 560 & 71 \\
Bottom 5 & 50 & 730 & -- & 175 & 360 & 86 \\
\hline
\end{tabular}

*The oxygen values are not representative because the oxygen is tied up with yttrium. 
During the final electron beam melting of the ingot, a malfunction of the molten pool-height control ram caused the molten vanadium to overflow the crucible, causing a premature shutdown. The portion melted was designated Heat Number 940021-V-52A. The remaining portion was melted into a separate ingot, Heat Number 940022-V-52A. Table V indicates the hardness and chemical data of the final ingots and shows that the ingots meet the requirements of the contract. A fourth ingot has been started during this quarter. Three batches of high purity. $\mathrm{V}_{2} \mathrm{O}_{5}$ from two sources, Vanadium Corporation of America and Kerr McGee, have been aluminothermically reduced. While the quantity of metal produced in these three reductions, 150 pounds, is not adequate to produce a full 100 pound ingot (a yield of 60 pounds is expected). Sufficient $\mathrm{V}_{2} \mathrm{O}_{5}$ of suitable purity was not available to produce a larger quantity. Material already procured at Wah Chang, had too high a silicon content. Wah chang is discussing the situation with the two suppliers of $\mathrm{V}_{2} \mathrm{O}_{5}$.

The furnace used in the reduction of the three derbies for the fourth ingot was slightly modified to decrease possible contamination of the material during the reduction process. Past experience has shown that a moderator was necessary to retard the rate of the aluminothermic reaction. Too violent a reaction caused excessive splattering and contamination. The furnace was modified by installing an $\mathrm{Al}_{2} \mathrm{O}_{3}$-lined steel lid over the reaction zone inside the furnace. This acts as a shield, reducing splattering and eliminating the need for an $\mathrm{Al}_{2} \mathrm{O}_{3}$ moderator. This further reduces the possibility of silicon contamination from the $\mathrm{Al}_{2} \mathrm{O}_{3}$.

Past experience has also shown that excess amounts of aluminum in the derbies (reductions) aid in the subsequent removal of oxygen during electron beam melting. 
TABLE V

CHEMICAL ANALYSIS INGOT \#3

Final Electron Beam Ingot Analysis (ppm)

\begin{tabular}{|c|c|c|c|c|c|c|}
\hline Heat No. & $\mathrm{C}$ & 0 & $\mathrm{H}$ & N & $\mathrm{Si}$ & $\begin{array}{c}\text { Hardness, BHN } \\
3,000 \mathrm{~kg}\end{array}$ \\
\hline $94002 I-V-52 \mathrm{~A}$ & \multirow[b]{2}{*}{110} & \multirow{3}{*}{360} & \multirow{3}{*}{5} & \multirow{3}{*}{199} & \multirow{3}{*}{610} & \multirow{3}{*}{$\begin{array}{l}116 \\
143\end{array}$} \\
\hline Top & & & & & & \\
\hline 2 & 90 & & & & & \\
\hline \multirow{2}{*}{$\begin{array}{l}\text { Bottom } 3 \\
940022-V-52 A\end{array}$} & 70 & 200 & 5 & 197 & 550 & 121 \\
\hline & & & & & & \\
\hline \multirow[t]{2}{*}{ Top } & 130 & 210 & 5 & 199 & \multirow[t]{2}{*}{520} & 137 \\
\hline & 80 & & & & & 116 \\
\hline Bottom 3 & 90 & 260 & 5 & 197 & 570 & 131 \\
\hline Average & 95 & 260 & 5 & 198 & 562 & 127 \\
\hline
\end{tabular}

TABLE VI

CHEMICAL ANALYSIS INGOT \#4

Derby Analysis (ppm)

\begin{tabular}{l|c|c|c|c|c}
\hline Derby No. & C & O & H & N & Si \\
\hline $11-13-67$ & 220 & 4,390 & -- & 45 & 210 \\
$11-17-67$ & 115 & 2,600 & -- & 65 & 100 \\
$11-27.67$ & 170 & 3,060 & -- & 125 & 400 \\
\hline Average & 168 & 3,350 & -- & 78 & 240 \\
\hline
\end{tabular}


Therefore, for the fourth ingot, a substantial amount (15\%) of excess aluminum was used to lower the oxygen content. Chemical analyses of the three derbies are shown in Table VI.

Two consolidation ingots were melted, one containing derbies 11-13-67 and 11-17-67, with 11-27-67 being melted separately since the silicon level of this material was marginal. Separation of the materials would not be necessary in a production operation provided a sufficiently pure pentoxide was available. Chemical and hardness data of the consolidation ingots are shown in Table VII.

The two ingots were second electron beam melted and designated Heat Number 940027-V-54B. The chemical and hardness data are shown in Table VIII. 
TABLE VII

CHEMICAL ANALYSIS INGOT \#4

Consolidation Ingot Analysis (ppm)

\begin{tabular}{|c|c|c|c|c|c|c|}
\hline Heat No. & $\mathrm{C}$ & 0 & $\mathrm{H}$ & $\mathrm{N}$ & $\mathrm{Si}$ & $\begin{array}{c}\text { Hardness, } B H N \\
3,000 \mathrm{~kg}\end{array}$ \\
\hline $940023-V-54 \mathrm{~A}$ & 370 & 420 & 3 & 180 & 380 & 217 \\
\hline (Derby $11-27-67$ ) & 290 & 290 & 9 & 170 & 270 & 181 \\
\hline \multirow{3}{*}{$\begin{array}{c}940026-V-54 \mathrm{~A} \\
\text { (Derbies } \\
11-13-67 \\
11-17-67 \text { ) }\end{array}$} & 270 & \multirow[t]{2}{*}{440} & \multirow[t]{2}{*}{4} & 110 & 390 & 86 \\
\hline & 230 & & & 100 & 310 & 109 \\
\hline & 310 & 200 & 5 & 90 & 300 & 116 \\
\hline Average & 290 & 340 & 5 & 130 & 330 & 142 \\
\hline
\end{tabular}

TABLE VIII

CHEMICAL ANALYSIS INGOT \#4

Second Electron Beam Ingot Analysis (ppm)

\begin{tabular}{l|c|c|c|c|c|c}
\hline Heat No. & C & O & H & N & Si & Hardness, BHN \\
\hline \multirow{4}{*}{$940027-V-54 B$} & 200 & 160 & 3 & 90 & 300 & 99 \\
& 140 & 170 & -- & 100 & 390 & 96 \\
& 130 & 130 & -- & 210 & 370 & 187 \\
& 140 & 430 & 8 & 200 & 480 & 170 \\
\hline \multirow{2}{*}{ Average } & 150 & 220 & 6 & 150 & 390 & 138 \\
& \\
&
\end{tabular}


The chemical analyses for the third ingot, shown below, indicate that the chemical requirements for the contract have been met.

\begin{tabular}{|c|c|c|c|c|}
\hline Element & $\begin{array}{l}\text { Target Value } \\
\text { (ppm) }\end{array}$ & $\begin{array}{l}\text { Contract } \\
\text { Requirement } \\
(\mathrm{ppm})\end{array}$ & 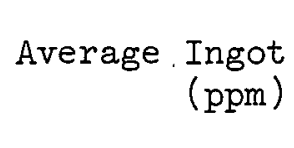 & Analysis \\
\hline Oxygen & 300 & 1 & 260 & \\
\hline Nitrogen & 100 & & 198 & \\
\hline Carbon & 100 & $\leq 500$ & 95 & 558 \\
\hline Hydrogen & 10 & J & 5 & \\
\hline Silicon & 500 & $\leq 500$ & 562 & \\
\hline Aluminum & 1000 & $\leq 1000$ & $<100$ & \\
\hline Iron & 1000 & $\leq 1000$ & 204 & \\
\hline
\end{tabular}

The variation in the interstitial and silicon contents ( 11 and $12 \%$ respectively), from the contract requirements, are within the accuracy of analyzing for these elements.*

*Verbal communication, Bureau of Mines, Albany, Oregon. 
The effects of vacuum melting on the hardness and chemistry of Ingot Nos. 2,3 and 4 are shown in Figures 1 through 5 .

Figure 1 shows the decreasing hardness of the ingots during purification. The reasons for the variation in hardness between the ingots are not obvious based upon the effects of individual constituents. It is suspected that the as-cast hardness is not the dead soft condition and therefore, cannot be taken as an effective measure of impurity levels. This was suggested by Rostoker and Hansen (Ref: Wright Air Force Development Center Technical Report 52-145, Part I, 1952) on cast buttons. In that investigation, molybdenum, beryllium and titanium all caused increases in the as-cast hardness, which could be subsequently lowered by annealing. It is likely that the interstitials and aluminum could behave similarly in vanadium.

It is also possible that the ingots are not totally homogeneous at this stage. A variation in grain size is noted along the length of the ingot. The size appears to vary inversely with the hardness. Sampling within these areas will be performed to detect the chemical variance.

The curves show decreasing hardness after each electron beam melt, with a slight increase after arc doping.

Figure 2, shows the effect of residual aluminum upon the rate of oxygen removal during electron beam melting. The greater residual aluminum content in the derbies for Ingot No. 3 (1.92 wt/O Al) and No. $4(15.4 \mathrm{wt} / 0 \mathrm{Al})$ versus Ingot No. 2 ( $0.92 \mathrm{wt} / \mathrm{OAl})$ greatly increases the rate of oxygen removal. Whereas previously, oxygen was removed during electron beam melting by the $\mathrm{C}+\mathrm{O}_{2} \rightarrow \mathrm{CO}_{2}$ process, it is removed now primarily by combining with the aluminum. Earlier in 
FIG. 1: EFFECT OF VACUUM MELTING ON THE HARDNESS READING OF VANADIUM

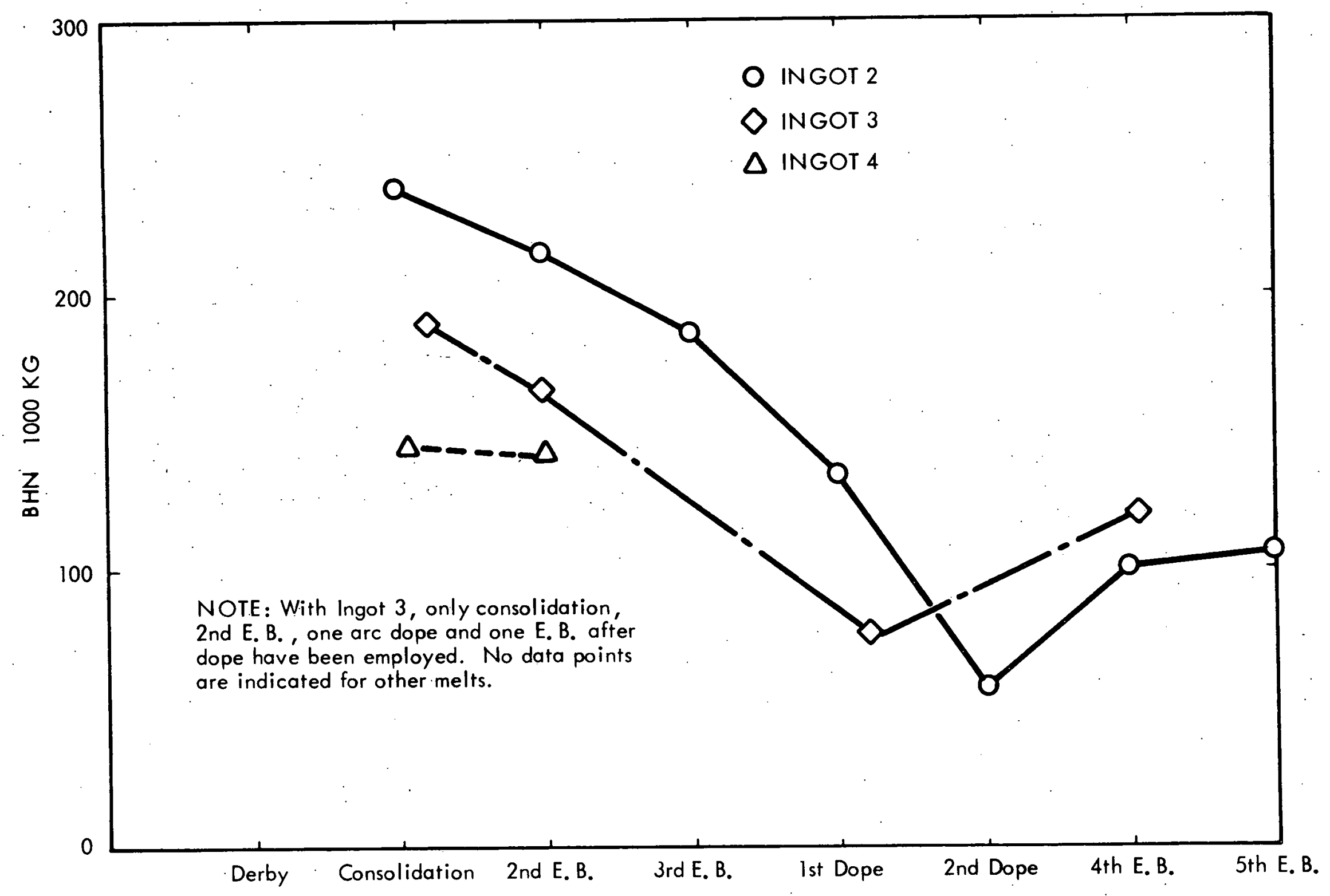


FIG. 2: EFFECT OF VACUUM MELTING ON THE OXYGEN CONTENT IN VANADIUM

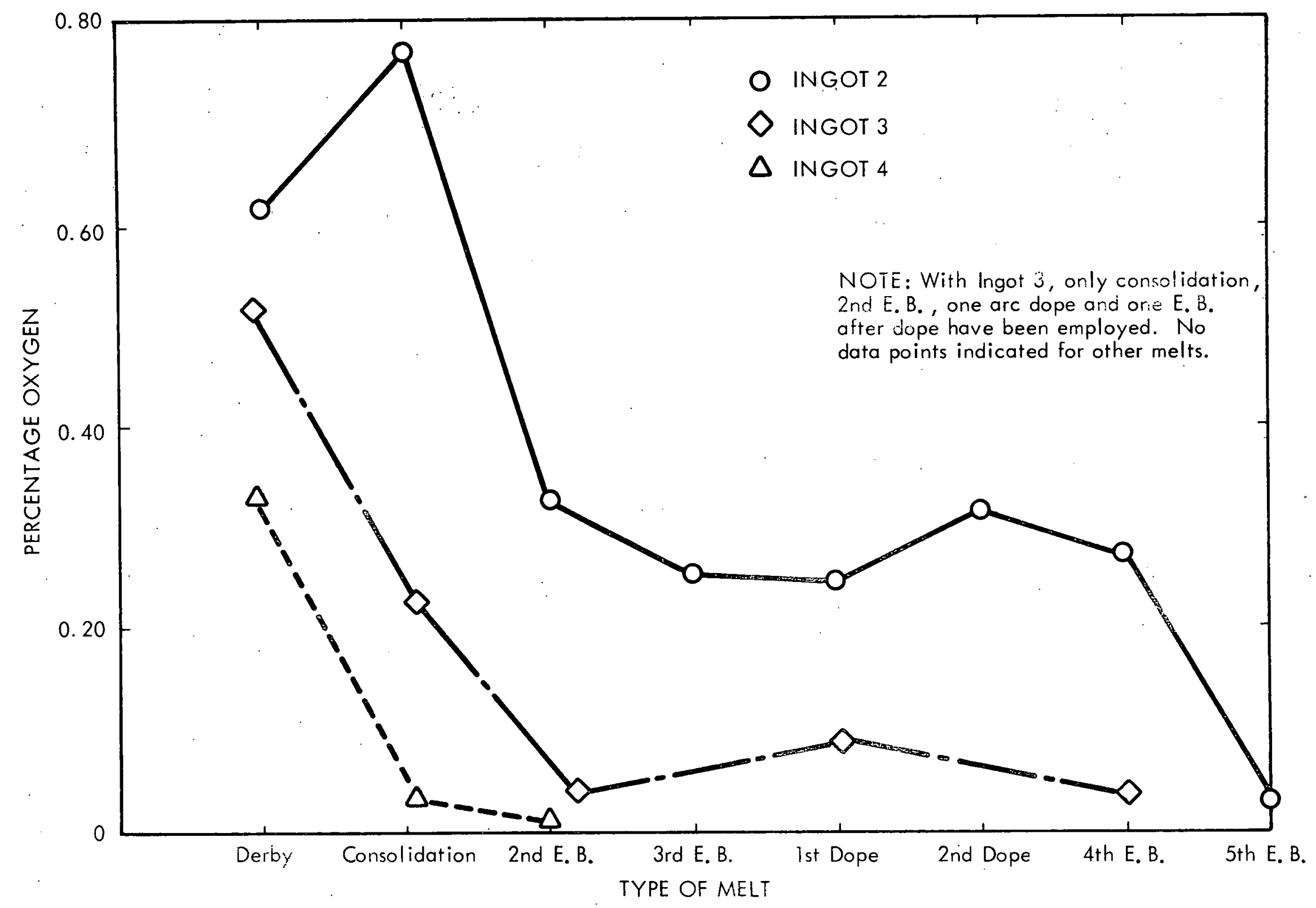


the program, it was felt that an excess of aluminum would lead to serious problems in electron beam melting, since arcing problems had been encountered in the melting of high aluminum, columbium thermite reductions. However, these problems were not encountered.

Figure 3 shows some inconsistancies which are probably a result of sampling errors and the heterogenious nature of the derbies and consolidation melt material. However, the data indicate that the carbon is not removed as rapidly when excess aluminum is retained in the derbies. Possibly, the excess aluminum reacts with the oxygen and reduces the oxygen available to react with the carbon.

Figure 4 shows that the nitrogen level can double during the complete process. It became obvious that nitrogen cannot be removed by vacuum melting, consequently, every effort must be made to avoid nitrogen contamination during all processing. Figure 5 shows that, neglecting inaccurate derby analyses, the silicon level remains essentially constant through the ingot production.

It is apparent that one of the major limitations in producing high purity vanadium metal is the quality of $\mathrm{V}_{2} \mathrm{O}_{5}$ available. This is especially true with. respect to silicon content since the two elements are so similar chemically and would be expected to behave similarly in thermite and electron beam operations. The chemical analyses of the fourth ingot after the second electron beam melt, show that the ingot, 77 pounds, already meets the chemical requirements without doping. The excess residual aluminum eliminates the doping step, further enhancing the process for commercial application. 
FIG. 3: EFFECT OF VACUUM MELTING ON THE CARBON CONTENT IN VANADIUM

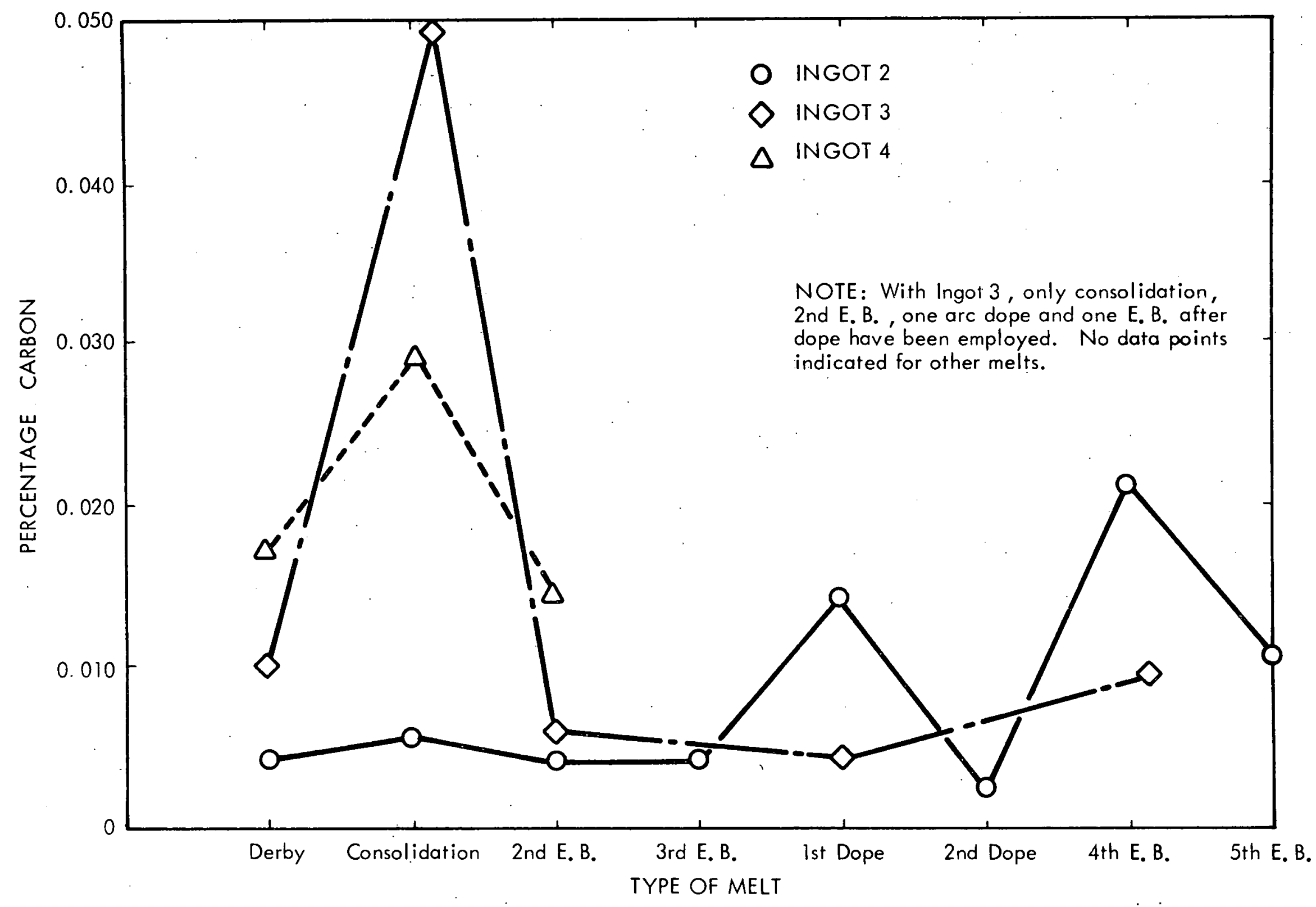


FIG. 4: EFFECT OF VACUUM MELTING ON THE NITROGEN CONTENT IN VANADIUM

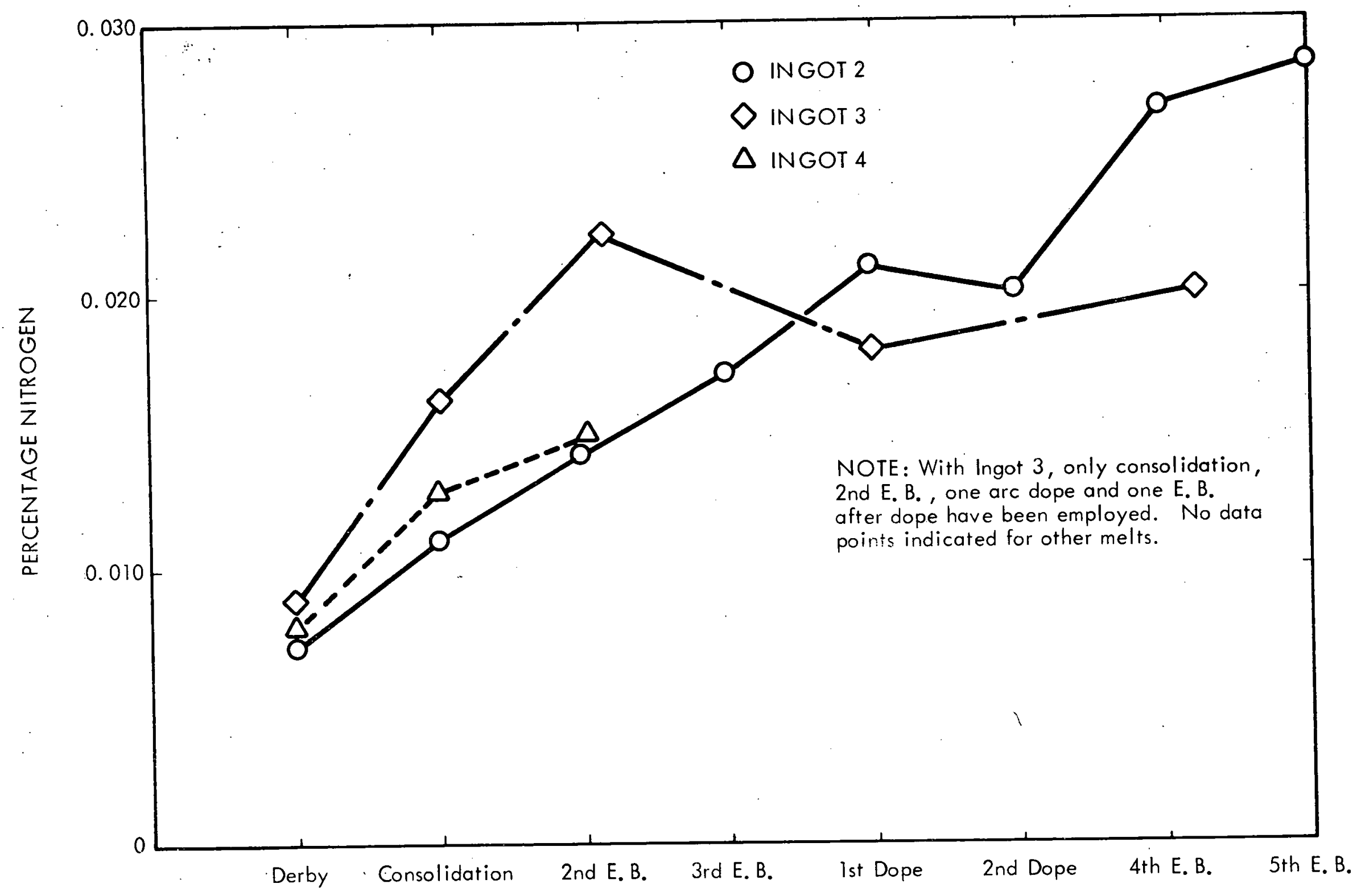


FIG. 5: EFFECT OF VACUUM MELTING ON THE SILICON CONTENT IN VANADIUM

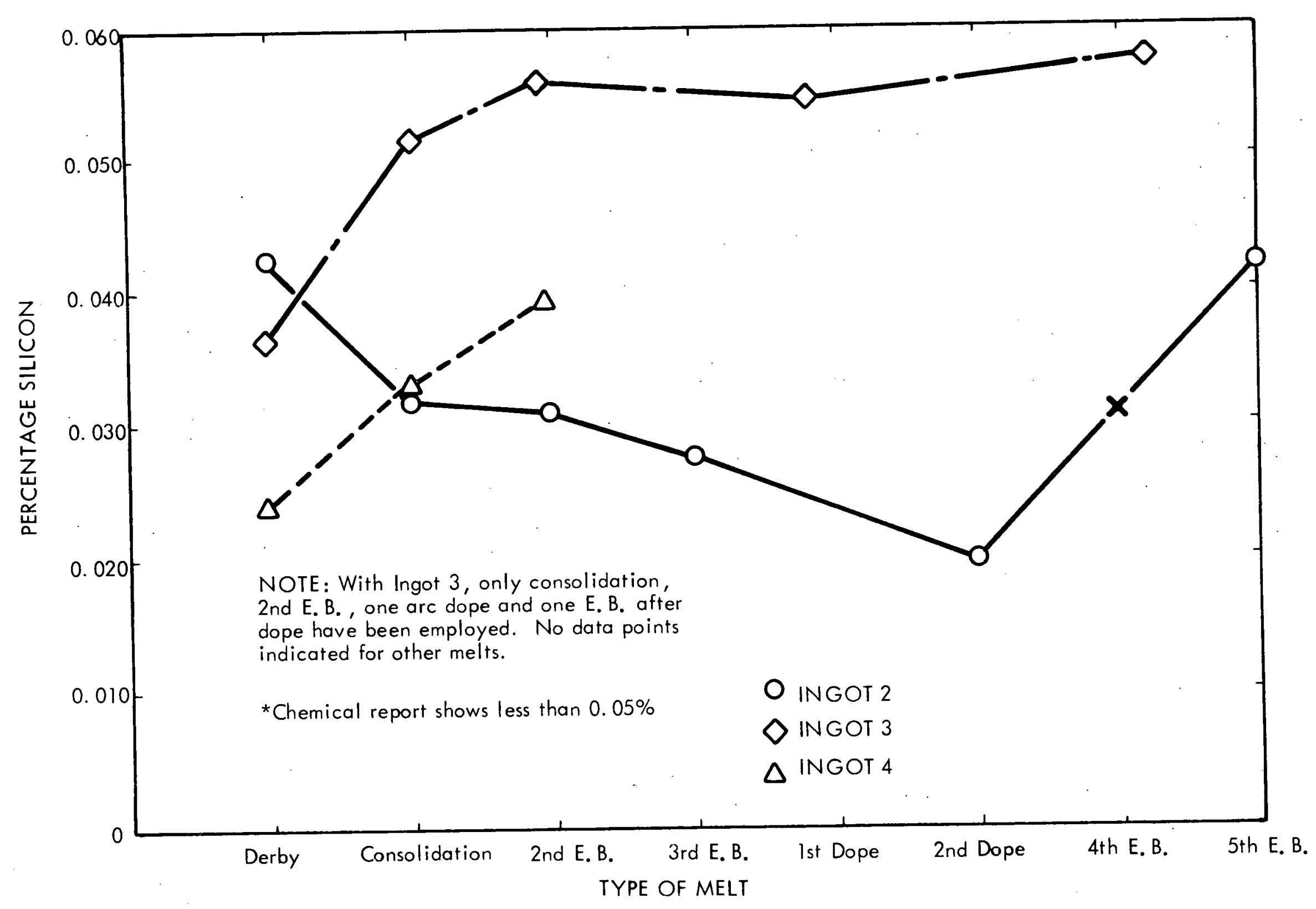




\section{FUTURE WORK}

When ingots 3 and 4 are accepted as satsifying contract requirements, the ingots shall be blended, as in the commercial processing of columbium and titanium, and processed into a single ingot of approximately 200 pounds. 100 pounds of this shall be used to produce a high purity V-15 Cr-5 Ti alloy. 
This report was prepared as an account of Government sponsored work. Neither the United States, nor the Commission, nor any person acting on behalf of the Commission:

A. Makes any warranty or representation, expressed or implied, with respect to the accuracy, completeness, or usefulness of the information contained in this report, or that the use of any information, apparatus, method, or process disclosed in this report may not infringe privately owned rights; or

B. Assumes any liabilities with respect to the use of, or for damages resulting from the use of any information, apparatus, method, or process disclosed in this report.

As used in the above, "person acting on behalf of the Commission" includes any employee or contractor of the Commission, or employee of such contractor, to the extent that such employee or contractor of the Commission, or employee of such contractor prepares, disseminates, or provides access to, any information pursuant to his employment or contract with the Commission, or his employment with such contractor. 